\title{
The Development Of Flash Program Based Mobile Learning (M-Learning) On Colloidal System Material
}

\author{
Nadia Armina Ramud \\ Program of Postgraduate, \\ State University of Medan \\ Medan, Indonesia \\ email : nramud2@gmail.com
}

\author{
Zainuddin Muchtar \\ Department of Chemistry Education \\ State University of Medan \\ Medan, Indonesia
}

\author{
Wesley Hutabarat \\ Department of Chemistry Education \\ State University of Medan \\ Medan, Indonesia
}

\begin{abstract}
This research was aimed to determine the level of feasibility of learning media chemistry that has been developed by using Adobe Flash CS6 program based on Mobile Learning (MLearning) on class XI semester 2 on the material colloidal system, to find out differences in learning outcomes who are taught by the media of learning chemistry on the material colloidal system that has been developed by using Adobe Flash CS6 program based on Mobile Learning (M-Learning) compared with the learning students who taught with learning chemistry media that has been circulated in internet on the same material. This type of research uses Development Research method that uses ADDIE. The research population is all students of class XI Senior High School using curriculum 13. The sample is the students of class XI Senior High School of Nurul Iman. The findings from the analysis show that learning media using Flash which has circulating on the internet sourced for high school class XI semester 2 on the material of colloidal system is feasible to use but need to be developed.
\end{abstract}

Keywords- media learning chemistry, colloidal system, Adobe Flash CS6, mobile learning

\section{INTRODUCTION}

Education is important for the progress and welfare of the nation. The development of science and technology in the era of globalization is so rapid. Technology is used as an innovative learning medium that is considered to be able to keep up with the times[1].In the learning process, the use of media is an inseparable part and is already something integrated with the learning method used. Learning media is used to help visualize teaching material that is abstract and also makes the learning process more interesting [2].Media can change student behavior (behavior change) and improve student learning outcomes. Changes in the behavior of students cannot take place spontaneously, but a comprehensive analysis is needed by taking into account various aspects that can affect the success of learning. These aspects include goals, conditions of students, supporting facilities, time available, and the ability of teachers to use them appropriately[3].

One of the compulsory school curriculum subjects is chemistry. Chemical learning is not enough to cover only cognitive aspects, but affective aspects (scientific attitudes) and psychomotor aspects [4].States that to be successful in chemistry requires a good understanding not by memorization. One chemical material that contains concepts and reactions chemical reactions that are abstract are colloidal systems. Colloidal system material which contains abstract concepts and reactions makes students feel bored in learning [5].

Based on the results of observations and interviews conducted in Nurul Iman Senior High School, that the learning outcomes in the principal of the colloidal system in the 2016/2017 school year have not reached the minimum completeness value of 80 , then the colloid learning process is usually done monotone, with the teacher system providing an explanation without using the media learning (conventional teaching), giving exercises - exercises contained in the textbook, so that students become bored, sleepy quickly and often students forget to bring books so students borrow textbooks.

Through technological advances, teachers can use various media according to the needs and goals of learning. One technology that can help create media is the Adobe Flash CS6 program combined with mobile learning using smartphones. Based on the research results can be concluded: (1) android based chemistry instructional media on colloids systems was successfully developed using adobe flash professional CS 6 and can be run on android devices (2) media that have been developed in terms of assessment material aspects and media aspects included in the very good category, and the test results to students included in the very good category, so it feasible to use in learning [6]

The results of research stated that the development of Flash Player animation media can be categorized as feasible to be used in the reaction rate material, where from the results of the validation questionnaire given to the three validators of the product being developed obtain an average value of $75 \%$ and based on observations of student activities during the learning process using Flash Player animated media products with the results of the average value obtained by $85 \%$ shows the activity of students can be categorized very well [7]. According research shows that the interactive multimedia learning media based on Adobe Flash CS6 produced is feasible 
to be used in learning chemical equilibrium in Vocational High Schools and getting positive responses from students [8]. Based on the research of Seraj dan Wong concluded that students consider mobile applications developed using Adobe Flash to be useful in learning. In addition, the application of mobile technology using Adobe Flash in designing online laboratories provides greater flexibility in student learning [9].

The results showed a significant difference between students' attitudes toward M-learning with respect to ownership, state, and age of their smartphone. Furthermore, the results show that M-learning can become one of the promising pedagogical technologies for employment in tertiary education in Saudi Arabia [10].

\section{RESEARCH METHOD}

This research is a development of instructional media by Adobe Flash CS6 program on collodial system material. The Research use Development Research method. Media development by Adobe Flash CS6 using ADDIE (Analysis, Design, Development, Implementation and Evaluation) steps. These steps include: (1) Analysis (analyzing the need for new development, analyzing the feasibility and requirements of developing new media), (2) Design (designing and preparing initial product or product design), (3) Development (realizing product design ), (4) Implementation (use of new learning media that has been developed in real situations in the classroom), (5) Evaluation (measuring the final competence of instructional media). The research instruments used to collect data are questionnaires and objective tests. Stages of development of learning media chemistry by using Adobe Flash CS6.

This research was conducted by Nurul Iman Senior High School, Deli Serdang Regency. The research subjects were students of class XI even semester 1 academic year 2017/2018 The population in this research were all students of class XI in Nurul Iman Senior High School, Deli Serdang Regency, academic year 2017/2018 who used the 2013 curriculum. The sample was selected using purposive sampling technique, that is from all students who were taken 24 students for classes taught with learning media Adobe Flash is based on mlearning developed (Experiment) and 24 people for classes taught with Flash learning media circulating on the internet (Control).

\section{RESEARCH RESULTS AND DISCUSSION}

Implementation of ADDIE model in designing and developing a learning media to create an effective and efficient classroom learning activity. The Steps in applying this development model need to be done gradually and carefully in order to achieve the desired goals. Before doing the development of instructional media, firstly done analysis to media of learning of chemistry using program of Adobe Flash CS6 which is available today either on internet or that have been used in school. Assessment standards for the analysis of available learning media ( $\mathrm{P}$ and $\mathrm{Q}$ learning media) use modified assessment standards from relevant journals that have been validated by expert teams. This analysis aims to get a learning media quality and feasible to use. The standard component of assessment in analyzing the available

TABLE 1. Standard Components of Assessment of Learning Media Analysis

\begin{tabular}{|c|c|}
\hline Aspect & Component \\
\hline View & $\begin{array}{l}\text { 1) Background of each media page, (2) Fonts and font } \\
\text { size used in each media page, (3) Use and suitability of } \\
\text { color proportions on each media page, (4) Display of } \\
\text { images on each media page, (5) Display (6) The overall } \\
\text { design of the media and its design conformity with the } \\
\text { learning materials, (7) the cover design and the main } \\
\text { menu, (8) the appearance of the media animation, (9) } \\
\text { the supporting / supporting view of the media }\end{array}$ \\
\hline
\end{tabular}

Relevance to (1) Conformity of material content to media with $\mathrm{KI}$, the matter KD, indicators and learning objectives, (2) Conformity of the content of the concept / theory to the media with the content of the concept / theory proposed by chemists / chemists, (3) Conformity of questions on the evaluation menu with learning materials, (4) Coverage of material content, (5) examples in the presentation of the material, (6) The ability of the media to improve the character of learners, (7) The ability of media for tools to understand and remember information, (8) Benefits

of the delivery of material content using the media in the practice of teaching and learning, (9) Quality presentation of the material

Programming (1) Ease of programming aspect, (2) Quality of navigation key, (3) Quality of navigation structure, (4) Use in running animation on media (simulation) to operate, (5) Access of operating system, (6) Capacity of program files

\begin{tabular}{ccc}
\hline & & \\
& & \\
& & \\
No & Percentage & Criteria \\
& & \\
\hline 1 & $80,00-100$ & Feasible \\
2 & $60,00-79,99$ & Quite Feasible \\
3 & $50,00-59,99$ & Less Worthy \\
4 & $0-49,99$ & not feasible \\
\hline
\end{tabular}

\section{A. Analysis of Learning Media P}

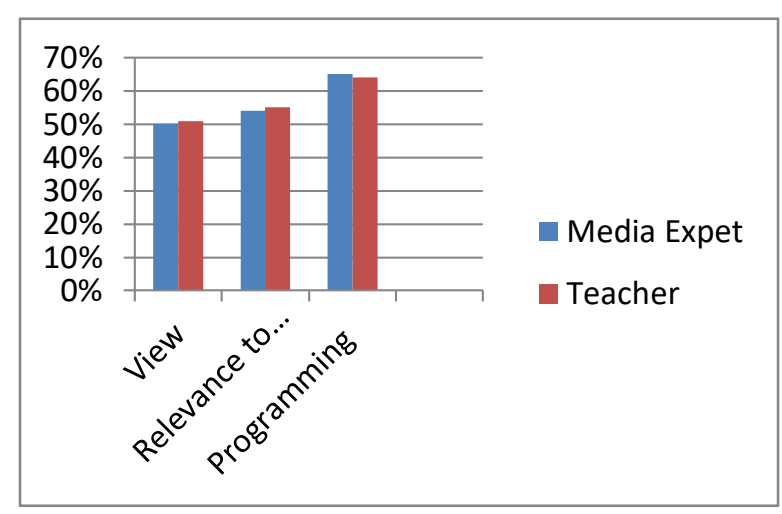

Fig 1. Percentage of Media Learning Eligibility 
The results of the $\mathrm{P}$ learning media analysis on the colloidal system material chemistry as a whole have a percentage which includes (1) media expert :50.00\% and teacher $51 \%$ (quite feasible) aspect of view, meaning that part of the learning media needs to be revised and needs to be developed. Media expert signed 54\%, teacher $55 \%$ (quite feasible), but still needs to be developed, (3) 65\% (media expert) and $64 \%$ (teacher) aspect programming (quite feasible), but still needs to be developed. Based on the results of the analysis can be identified deficiencies contained in the $\mathrm{P}$ learning media of colloidal system material. For the appropriateness of the appearance of the learning media $\mathrm{P}$ is quite feasible but still needs to be revised further and developed again, then but needs further revision and development. For example in the appearance of the cover design, and supporting media components. The feasibility of the material in P learning media is quite feasible but still needs to be developed, some material or sample questions are not discussed thoroughly so that further development is needed. For example in the scope of content, the ability of the media to improve the character of students. In the programming feasibility analysis on learning media $\mathrm{P}$ is quite feasible, but needs to be developed. For example on the quality of navigation buttons, the quality of the navigation structure.

\section{B. Analysis of Learning Media $Q$}

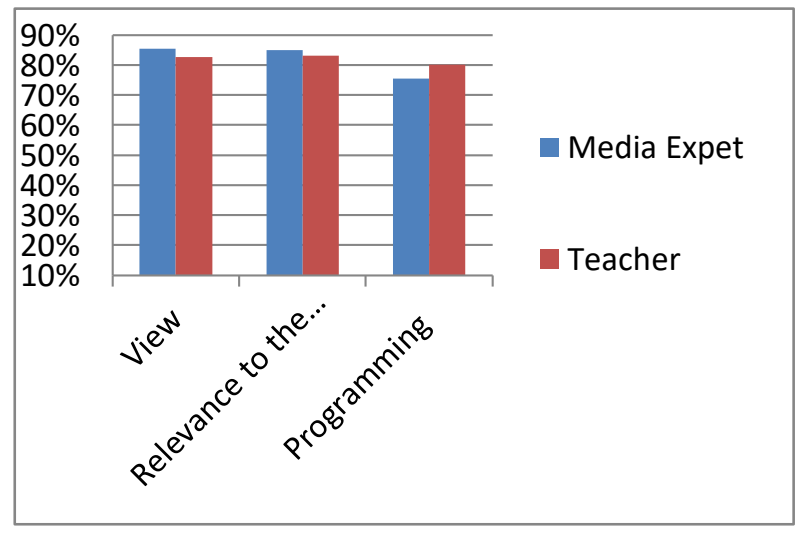

Fig 2. Percentage of Media Learning Eligibility Q

The result of $\mathrm{Q}$ learning media analysis on collodial system material as a whole has percentage covering (1) aspect of view of media expert : $85,3 \%$ and teacher $85 \%$ (quite feasible) meaning some of instructional media display need to be revised and need to be developed, (2) aspect of relevance to the matter to media expert $75,56 \%$, teacher $83 \%$ (quite feasible), but still needs to be developed, (3) programming aspect of media expert $75,5 \%$ and teacher $80 \%$ (quite feasible), but still needs to be developed.

Based on the results obtained based on the assessment aspects that have been rated by the media expert and teacher between the media that has been circulating $(\mathrm{P})$ with the media developed (Q) that the media developed from the media that has been circulating before, the media needs to be further developed so that the media which has been developed into a better quality learning resource and is expected to be a learning medium that can improve student learning achievement.

\section{CONCLUSION}

The conclusion of the study the development of flash program based mobile learning (M- Learning) on colloidal system material in class XI Senior High School of Nurul Iman that results of analysis on m-learning based flash learning media are good, and there are still many development processes that need to be revised, in accordance with the results of the analysis carried out in every aspect, so that the development of flash media becomes better, innovative and effective in learning.

\section{REFERENCES}

[1] Lubis, I.R, Solihah.M, Sugiyarto dan Ikhsan,J, "Pengembangan Media Mobile Learning "Chemondro" Berbasis Android Sebagai Suplemen Belajar Siswa SMA”, Prosiding Seminar Nasional Pendidikan Sains (SNPS) ,pp.468-477,2015

[2] Sari, K.W, Saputro.S dan Hastuti. B, "Pengembangan Game Edukasi Kimia Berbasis Role Playing Game (Rpg) Pada Materi Struktur Atom Sebagai Media Pembelajaran Mandiri Untuk Siswa Kelas X Sma Di Kabupaten Purworejo", Jurnal Pendidikan Kimia (JPK), vol 3 (2), pp. 96 104, 2014

[3] Apriyani, T. (2015). Pengembangan Media Pembelajaran Interaktif Adobe Flash Cs5 Untuk Meningkatkan Keterampilan Membaca Teks Pendek Bahasa Prancis Siswa Kelas Xi Sma El Shadai Magelang.Skripsi.Yogyakarta : Universitas Negeri Yogyakarta

[4] Zakiah, "Pengembangan Penuntun Praktikum Tipe Discovery dan Project Based Learning pada Pembelajaran Larutan Elektrolit dan Nonelektrolit di SMA”, Jurnal Pendidikan Kimia, Vol 7(11),pp. 70-79, 2015

[5] Bunce,D.M,"Teaching is More Than Lecturing and Learning is More Than Memorizing",Journal of Chemical Education, vol. 86(6) , pp. 674-680, 2009

[6] Irwanto,I, K.Sugiarto dan J.Ikhsan,"Android-based colloids systems instructional media: multiplicities of place", Proceeding of International Seminar on Science Education, ISSN: 2476-9533, 2015

[7] Fuady, C.A,'Pengembangan media animasi flash player pada materi laju reaksi di SMK Negeri 1 Banda Aceh", Jurnal Pendidikan dan Teknologi Informasi, vol 1(1), pp. 34-47, 2015

[8] Saselah. Y.R, Amir. M dan Qadar.R,'Pengembangan Multimedia Interaktif Berbasis Adobe Flash CS6 Professional Pada Pembelajaran kesetimbangan Kimia”, Jurnal Kimia \& Pendidikan Kimia, vol 2 (2),pp. 80-89, 2017

[9] Seraj, M and Wong, C.Y," A Study of User Interface Design Principles and Requirements for Developing a Mobile Learning Prototype'.International Conference on Computer \& Information Science, 2012

[10] Al-emran, M, Shaalan, K, Elsherif, H,'Investigating Attitudes Towards The Use of Mobile Learning in Higher Education", Elsevier Journal, vol 6, pp. 93-102, 2016 